\title{
Single Screw Extrusion Processing of Soy White Flakes Based Catla Feed
}

\author{
Sushil Kumar Singh ${ }^{1} \&$ Kasiviswanathan Muthukumarappan ${ }^{1}$ \\ ${ }^{1}$ Department of Agricultural \& Biosystems Engineering, South Dakota State University, Brookings, SD, USA \\ Correspondence: Sushil Kumar Singh, Department of Agricultural and Biosystems Engineering, South Dakota \\ State University, Brookings, SD, USA. E-mail: sushil.singh@sdstate.edu; sksingh32325@gmail.com
}

Received: September 10, 2014 Accepted: October 3, 2014 Online Published: October 5, 2014

doi:10.5539/jfr.v4n1p1

URL: http://dx.doi.org/10.5539/jfr.v4n1p1

\begin{abstract}
An initial investigation into the inclusion of soy white flakes (SWF) and high protein distillers dried grains (HP-DDG) in catla (Catla catla) diet, belonging to the family Cyprinidae, was conducted using a single screw extruder. Three isocaloric $(302 \mathrm{kcal} / 100 \mathrm{~g})$ ingredient blends containing graded levels of SWF in combination with HP-DDG and other required ingredients were formulated to contain a net protein content of $31.5 \%$ (wet basis). Extrusion processing was then performed using three levels each of SWF content, moisture content, and temperature gradient keeping a constant screw speed and die diameter. Effects of these variables on extrudate physical properties including: color, pellet durability index, bulk density, water absorption index, water solubility index, unit density and expansion ratio were extensively analyzed. Increasing the level of SWF resulted in increase in water absorption index and unit density but decrease in expansion ratio. The interaction effect of SWF content, moisture content and temperature were significant for color, pellet durability index, bulk density and expansion ratio. All the extrudates showed relatively high pellet durability and inclusion of SWF produced less expanded and more compact textured extrudates.
\end{abstract}

Keywords: aquafeed, expansion ratio, extrusion, soy white flakes, water absorption index, water solubility index

\section{Introduction}

Extrusion is a versatile and very efficient technology that is widely used in food and feed processing including increasing numbers of ready-to-eat cereals, salty and sweet snacks, coextruded snacks, indirect expanded products, croutons for soups and salads, an expanding array of dry pet foods and fish foods, textured meat-like materials from defatted high-protein flours, nutritious precooked food mixtures for infant feeding, and confectionery products (Mercier et al., 1989). Extrusion cooking is a high-temperature, short-time process in which starchy and/or proteinaceous food materials are plasticized, cooked, and in some cases expanded by a combination of moisture, pressure, heating, and mechanical shear, resulting in molecular transformation and chemical reactions. It provides a continuous high throughput processing and can be controlled automatically. It can be used to produce products with various shape, color, texture and appearance.

Protein is the most important nutrient which promotes growth in fishes. Depending on the fish species, fish feed generally requires protein content of $26 \%$ to $50 \%$ (Lovell, 1989). Commonly, high amount of ground marine caught fish as fish meal, are used to meet the requirement of protein in fishes which contributes significantly to variable production cost in aquaculture industry. However, decreasing fishmeal supply relative to demand and increasing costs threaten the sustainability and growth of the aquaculture industry. Approximately two to six pounds of marine fish are needed for the production of only one pound of farm fish (Marine Aquaculture Task Force, 2007). As protein is the costliest among various ingredients in preparation of fish feeds, it is necessary to search for the alternative protein sources in order to reduce the cost of feeds (Renukaradhya \& Varghese, 1986; FAO, 2004; Lunger et al., 2007). Hence, the goal is to minimize fish meal inclusion in fish feed by substituting appropriate alternative protein sources (Hardy \& Masumoto, 1990). A number studies of have been done regarding the efficacy of plant feedstuffs as alternative protein sources in fish feeds (Hossain \& Jauncey, 1989).

High protein distillers dried grains (HP-DDG) and soy white flakes (SWF) can be used as an alternative source of protein. Distillers Dried Grains (DDG) and Distillers Dried Grains with Solubles (DDGS), a co-product from corn-based dry grind fuel ethanol manufacturing, is a viable protein source. Typically, DDGS contains approximately $30 \%$ protein (Rosentrater \& Muthukumarappan, 2006; Spiehs et al., 2002) whereas DDG contain 
1.5 times more protein that of DDGS and less fat; hence, it is called HP-DDG (Robinson \& Li, 2008). Moreover, HP- DDG provides higher available phosphorous content thus reducing the need for phosphorous supplementation and its nutritional values are much more consistent than those of DDGS (Robinson et al., 2008). Fallahi et al. (2013) reported that inclusion of HP-DDG up to $40 \%$ led to the production of more expanded and floatable extrudates compared to those extrudates containing DDGS for rainbow trout. Soy is one of the most important protein-rich plants and a source of protein for aquafeeds (Morris et al., 2005; Francesco et al., 2007; Karalazos et al., 2007). Use of soy products like full fatted soybean meal, defatted toasted soybean meal (SBM) and defatted untoasted soybean meal or white flakes (WF) is becoming common (Fallahi et al., 2012). Romarheim et al. (2005) found that extrusion of WF diet increased the digestibility of protein and all amino acids whereas fishmeal and SBM had no significant effect on amino acid digestibility. Dersjant-Li, (2002) reported that soy protein isolate can be used to replace $40-100 \%$ fish meal without negative impact on growth performance of shrimp. To date, however, no trials of partial or complete replacement of fishmeal with SWF and HP-DDG for fish feeds have been conducted.

Therefore, the objectives of this study were to produce feed pellets for catla (Catla catla) with SWF and HP-DDG inclusions and to examine the effect of various levels of SWF content, moisture content and extruder barrel temperature on physical properties of the extruded feeds.

\section{Materials and Methods}

SWF were kindly donated by South Dakota Soybean Processors (Volga, SD). Corn flour was purchased from Cargill Dry Ingredients (Paris, IL). HP-DDG was obtained from the Dakota Ethanol LLC (Wentworth, SD). Corn gluten meal (CGM) and fishmeal were purchased from Consumer Supply Distributing Co. (Sioux City, IA). Vitamin-mineral premix was obtained from Lortscher Agri Service, Inc. (Bern, Kansas, USA). Soybean oil was obtained from USDA (Brookings, SD).

\subsection{Blend Formulation}

Three isocaloric ( $302 \mathrm{kcal} / 100 \mathrm{~g}$ ) blends were formulated to contain a net protein content of $31.5 \%$ (wet basis) and a target fat content of $\sim 4.2 \%$. The total energy content for each blend was determined based on the fraction of protein, fat and carbohydrate contributing to the dietary energy. The total energy content was calculated based on the energy content of fractions namely, $4.5 \mathrm{kcal} / \mathrm{g}$ for protein, $9.1 \mathrm{kcal} / \mathrm{g}$ for lipid and $4.1 \mathrm{kcal} / \mathrm{g}$ for carbohydrate. The different ingredients in the blends include SWF (42.5\% protein), HP-DDG ( $42 \%$ protein and $4.5 \%$ fat), corn gluten meal, corn flour, fish meal, soybean oil, and vitamin \& mineral mix (Table 1). The ingredients were mixed in a laboratory scale Hobart mixer (Hobart Corporation, Troy, Ohio, USA) for 10 minutes and stored overnight at ambient temperature $\left(25^{\circ} \mathrm{C}\right)$ for moisture stabilization. The moisture balancing of the blends was done by adding required quantities of water during mixing.

Table 1. Ingredient composition of feed blends

\begin{tabular}{lccc}
\hline Feed ingredients & \multicolumn{3}{c}{ Mass of ingredients $(\mathrm{g} / 100 \mathrm{~g})$} \\
\hline SWF & Blend I & Blend II & Blend III \\
HP-DDG & 10 & 20 & 30 \\
Corn gluten meal & 40 & 30 & 20 \\
Corn flour & 7 & 7 & 7 \\
Fish meal & 35 & 35 & 35 \\
Soybean oil & 5 & 5 & 5 \\
Vitamin \& mineral mix & 1 & 1 & 1 \\
Total & 2 & 2 & 2 \\
\hline
\end{tabular}

\subsection{Extrusion Processing}

The extrusion processing was performed using a single screw extruder (Brabender Plasti-Corder, Model PL 2000, South Hackensack, NJ) which was powered by a $7.5 \mathrm{hp}$ motor with an operating range of screw speeds from 0 to $210 \mathrm{rpm}$ ( 0 to $22 \mathrm{rad} / \mathrm{s})$. The extruder had a barrel with length-to-diameter ratio of 20:1 and a barrel diameter (D) 
of $19 \mathrm{~mm}$. A uniform $19.05 \mathrm{~mm}$ pitch screw with compression ratio of 3:1 was used in the experiments. The clearance $(\mathrm{H})$ between the inner wall of the barrel and screw at die section is $1.27 \mathrm{~mm}(0.05 \mathrm{in})$ and the clearance $(3 \mathrm{H})$ between the inner wall of the barrel and screw at feed section is $3.81 \mathrm{~mm}(0.15 \mathrm{in})$. A typical screw of a single screw extruder is shown in Figure 1.

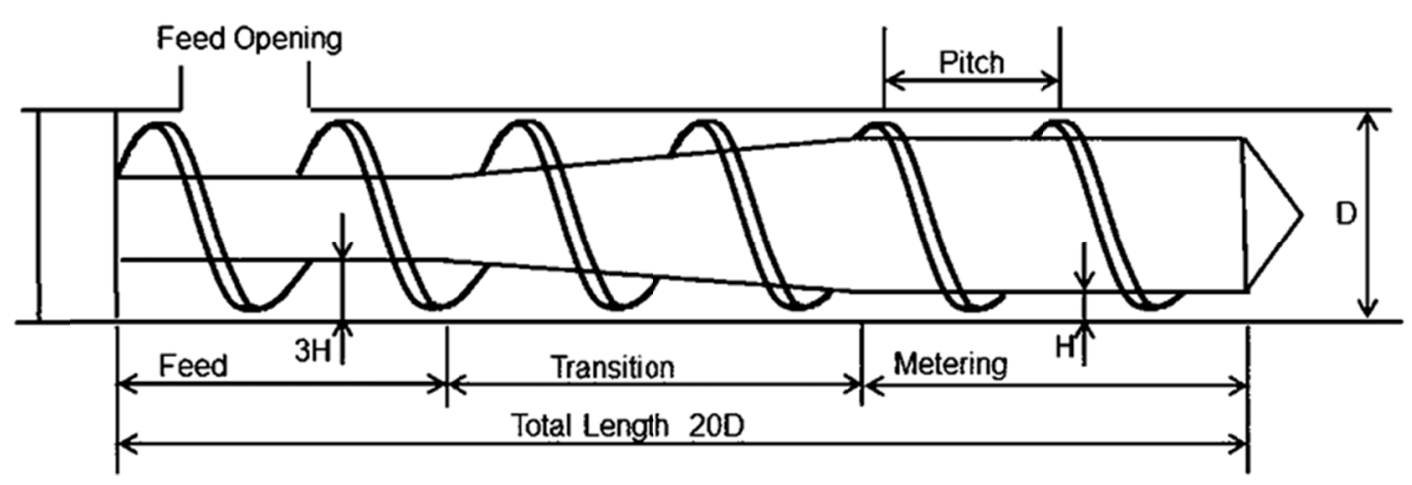

Figure 1. Schematic representation of screw in a single screw extruder

The length and diameter of the die nozzle was $17.5 \mathrm{~mm}$ and $3 \mathrm{~mm}$ (L/D: 5.83), respectively. The extruder barrel was equipped with external band heaters with provisions to control the temperature of all three zones: feed zone, transition zone/melting zone, and die sections (Figure 2).

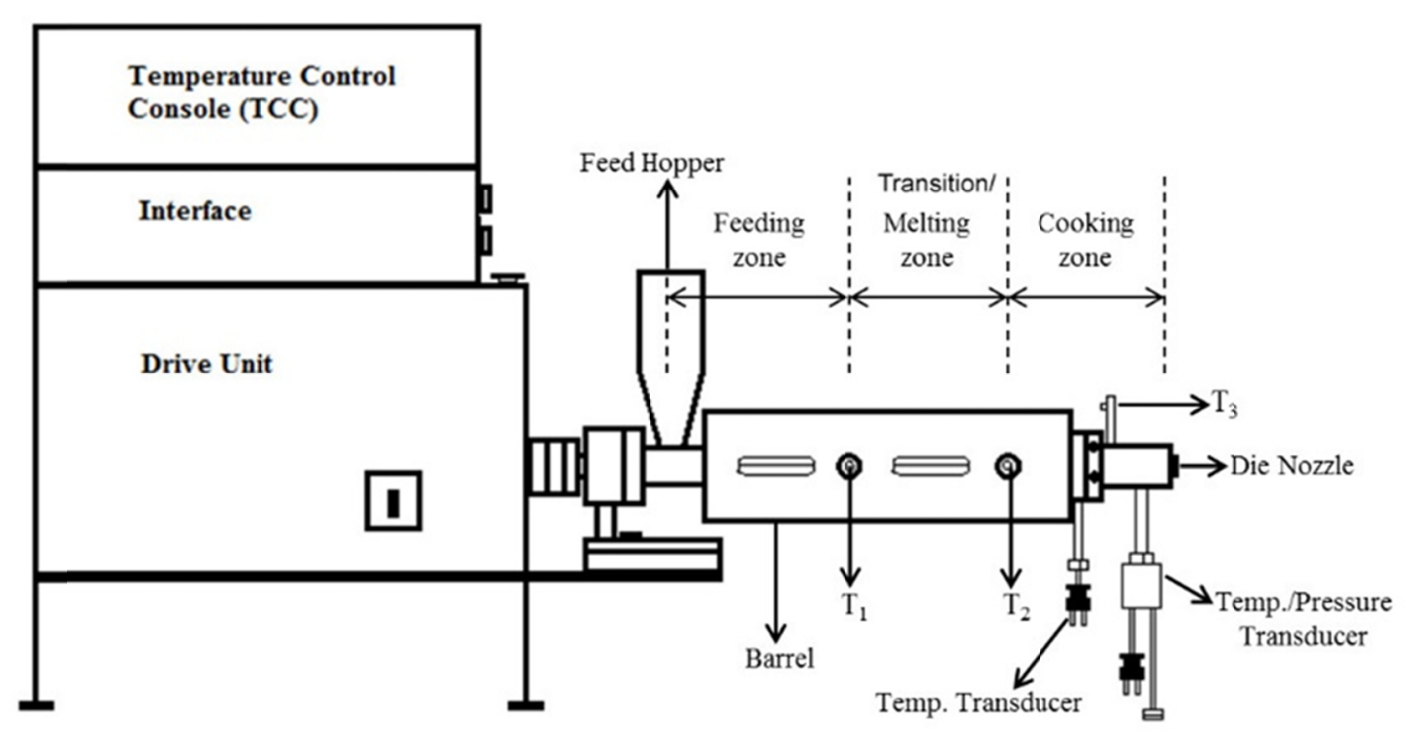

Figure 2. Schematic representation of laboratory extruder (Brabender Plasti-Corder, Model PL 2000)

The raw materials were fed in feeding zone of the extruder through feed hopper. It got gelatinized and plasticized under thermal and mechanical stresses generated by the rotation of screws in melting zone of the extruder. The gelatinized material then enters the cooking zone where the extruder barrel is fully filled due to pressure generated at die nozzle. When the process reached the steady state, samples were collected at the die. All samples were left to dry at ambient temperature $\left(25^{\circ} \mathrm{C}\right)$ for 48 hours prior to further analysis. During the experiment the screw speed of extruder was maintained at $150 \mathrm{rpm}$.

\subsection{Experimental Design and Analysis}

Experiments were conducted using a full factorial, three-level design, with SWF content, moisture content, and barrel temperature gradient levels being the independent variables. This resulted in 27 unique extrusion trials for different combinations of three levels each of SWF content $(10 \%, 20 \%$, and $30 \%)$, moisture content $(15 \%, 25 \%$, 
and $35 \% \mathrm{db}$ ), and temperature gradient (T1-T2-T3) in the barrel $\left(45-110-110{ }^{\circ} \mathrm{C}, 45-140-140{ }^{\circ} \mathrm{C}\right.$, and $45-170-170$ ${ }^{\circ} \mathrm{C}$ ), hereafter referred as temperature of 110,140 and $170{ }^{\circ} \mathrm{C}$. Each treatment was extruded once and three replicates were determined for all the extrudate physical properties, except unit density which was measured with ten replicates. All the collected data were analyzed with SAS v.9 (SAS Institute, Cary, NC). The Proc GLM procedure was used to determine the main, treatment and interaction effects using a Type I error rate $(\alpha)$ of 0.05 . Post-hoc least significant differences (LSD) tests were used to identify where the significant differences occurred.

\subsection{Measurement of Physical Properties}

\subsubsection{Color}

A spectrophotometer (LabScan XE, HunterLab, Reston, VA) was used to determine extrudate color, where L* quantified the brightness/darkness, $a^{*}$ the redness/greenness and $b^{*}$ the yellowness/blueness of the extrudate samples.

\subsubsection{Pellet Durability Index (PDI)}

Approximately $100 \mathrm{~g}$ of extrudates from each blend were manually sieved (U.S.A. standard testing, ASTM E-11 specification, Daigger, Vernon Hills, IL) to remove initial fines, and then tumbled in a pellet durability tester (Model PDT-110, Seedburo Equipment Company, Chicago, IL) for $10 \mathrm{~min}$. Afterwards, the samples were again sieved, and then weighed on an electronic balance (ASAE, 2004). PDI was calculated as:

$$
\operatorname{PDI}(\%)=\left(\frac{M_{a}}{M_{b}} \times 100\right)
$$

where, $\mathrm{M}_{\mathrm{a}}$ was the mass (g) after tumbling and $\mathrm{M}_{\mathrm{b}}$ was the sample mass (g) before tumbling.

\subsubsection{Bulk Density (BD)}

Bulk density was determined as the ratio of the mass of extrudates that they filled up to a given bulk volume and measured using a standard bushel tester (Seedburo Equipment Company, Chicago, IL) following the method recommended by USDA (1999).

\subsubsection{Water Absorption Index (WAI) and Water Solubility Index (WSI)}

Extrudates were ground to fine powders using a coffee grinder (Black \& Decker ${ }^{\circledR}$ Corporation, Towson, ML, USA). The ground extrudates $(2.5 \mathrm{~g})$ was suspended in distilled water $(30 \mathrm{~mL})$ in a tarred $60 \mathrm{~mL}$ centrifuge tube. The suspension was stirred intermittently and centrifuged at $3000 \mathrm{~g}$ for $10 \mathrm{~min}$. The supernatant was decanted into a tarred aluminums cup and dried at $135^{\circ} \mathrm{C}$ for $2 \mathrm{~h}$ (AACC, 2000). The weight of the gel remaining in the centrifuge tube was measured. The WAI and WSI were calculated by:

$$
W A I \text { (unitless) }=\left(\frac{W_{g}}{W_{d s}}\right)
$$

where, $\mathrm{W}_{\mathrm{g}}$ is the weight of gel (g), and $\mathrm{W}_{\mathrm{ds}}$ is the weight of dry sample $(\mathrm{g})$.

$$
\operatorname{WSI}(\%)=\left(\frac{W_{s s}}{W_{d s}} \times 100\right)
$$

where, $\mathrm{W}_{\mathrm{ss}}$ is the weight of dry solids of supernatant ( $\mathrm{g}$ ), and $\mathrm{W}_{\mathrm{ds}}$ is the weight of dry sample (g).

\subsubsection{Unit Density (UD) and Expansion Ratio (ER)}

The extrudates were cut to a length of $\sim 1$ inch $(25.4 \mathrm{~mm})$ and weighed on an analytical balance (Adventurer ${ }^{\mathrm{TM}}$, Item No: AR 1140, Ohaus Corp. Pine Brook, NJ), then measured with a digital calliper (Digimatic calliper, Model No: CD-6"C, Mitutoyo Corp., Tokyo, Japan) to determine their diameter. The unit density (UD, g/cm ${ }^{3}$ ) was calculated as the ratio of the mass $\mathrm{M}(\mathrm{g})$ to the volume $\mathrm{V}\left(\mathrm{cm}^{3}\right)$ of each measured and weighed extrudate sample, assuming a cylindrical shape for each extrudate (Rosentrater et al., 2005):

$$
U D(g / c c)=\left(\frac{M}{V}\right)
$$

The radial expansion ratio of the extrudates was measured as the ratio of the diameter of the extrudates to the 
diameter of the die orifice.

\section{Results and Discussion}

\subsection{Color}

Change in color of extrudates can be an indication of nutrients degradation during extrusion processing (Bjorck \& Asp, 1983). Increasing the SWF content from $10 \%$ to $30 \%$ resulted in $1.2 \%$ increase in $L^{*}$ value but $6.9 \%$ decrease in $a^{*}$ value and $3.5 \%$ decrease in $b^{*}$ value (Table 2). Change in $a^{*}$ value can be due to the difference in color of the raw material used before extrusion. Decrease in yellowness of extrudate was expected because raw DDG was yellowish in color; thus, decrease in DDG content or increase in SWF content (Table 1) resulted in a significant decrease in yellowness of the extrudate. Increasing the moisture content of ingredient blends from $15 \%$ to $35 \%$, led to significant decrease in $\mathrm{L}^{*}$ and $\mathrm{b}^{*}$ values by $28.0 \%$ and $23.0 \%$, respectively. Increasing moisture content in blends had significant effect on $a^{*}$ value but no particular trend was observed (Table 2). Likewise, increasing extruder barrel temperature from $110{ }^{\circ} \mathrm{C}$ to $170{ }^{\circ} \mathrm{C}$ resulted in significant change $(\mathrm{p}<0.05$, Table 3) in $\mathrm{L}^{*}, \mathrm{a}^{*}$ and $\mathrm{b}^{*}$ values but no specific trends were discernible.

Table 2. Main effects of SWF content, moisture content of raw material and temperature profile (on extrudate physical properties) *

\begin{tabular}{|c|c|c|c|c|c|c|c|c|c|}
\hline Variable & $\begin{array}{l}\mathrm{L}^{*} \\
(-)\end{array}$ & $\begin{array}{l}a^{*} \\
(-)\end{array}$ & $\begin{array}{l}b^{*} \\
(-)\end{array}$ & $\begin{array}{l}\text { PDI } \\
(\%)\end{array}$ & $\begin{array}{c}\text { BD } \\
(\mathrm{g} / \mathrm{cc})\end{array}$ & $\begin{array}{c}\text { WAI } \\
(-)\end{array}$ & $\begin{array}{l}\text { WSI } \\
(\%)\end{array}$ & $\begin{array}{c}\text { UD } \\
(\mathrm{g} / \mathrm{cc})\end{array}$ & $\begin{array}{c}\text { ER } \\
(-)\end{array}$ \\
\hline \multicolumn{10}{|l|}{ SWF (\%) } \\
\hline 10 & $\begin{array}{l}41.93^{b} \\
(6.11)\end{array}$ & $\begin{array}{l}6.20^{\mathrm{a}} \\
(0.88)\end{array}$ & $\begin{array}{l}15.45^{\mathrm{a}} \\
(1.67)\end{array}$ & $\begin{array}{l}88.01^{b} \\
(5.30)\end{array}$ & $\begin{array}{c}0.36^{\mathrm{c}} \\
(0.05)\end{array}$ & $\begin{array}{c}3.98^{b} \\
(0.60)\end{array}$ & $\begin{array}{c}14.03^{\mathrm{ab}} \\
(1.51)\end{array}$ & $\begin{array}{c}0.89^{\mathrm{b}} \\
(0.15)\end{array}$ & $\begin{array}{l}1.17^{\mathrm{a}} \\
(0.07)\end{array}$ \\
\hline 20 & $\begin{array}{l}42.06^{\mathrm{b}} \\
(6.25)\end{array}$ & $\begin{array}{c}5.99^{\mathrm{b}} \\
(0.89)\end{array}$ & $\begin{array}{l}15.17^{b} \\
(1.89)\end{array}$ & $\begin{array}{l}85.73^{\mathrm{c}} \\
(6.37)\end{array}$ & $\begin{array}{l}0.39^{\mathrm{a}} \\
(0.05)\end{array}$ & $\begin{array}{c}4.07^{\mathrm{b}} \\
(0.67)\end{array}$ & $\begin{array}{l}13.66^{\mathrm{b}} \\
(1.27)\end{array}$ & $\begin{array}{l}0.92^{\mathrm{a}} \\
(0.16)\end{array}$ & $\begin{array}{l}1.13^{\mathrm{b}} \\
(0.12)\end{array}$ \\
\hline 30 & $\begin{array}{l}42.42^{\mathrm{a}} \\
(6.63)\end{array}$ & $\begin{array}{l}5.77^{\mathrm{c}} \\
(0.92)\end{array}$ & $\begin{array}{l}14.91^{\mathrm{c}} \\
(2.10)\end{array}$ & $\begin{array}{l}89.97^{\mathrm{a}} \\
(4.62)\end{array}$ & $\begin{array}{c}0.38^{\mathrm{b}} \\
(0.04)\end{array}$ & $\begin{array}{l}4.26^{\mathrm{a}} \\
(0.63)\end{array}$ & $\begin{array}{l}14.21^{\mathrm{a}} \\
(1.79)\end{array}$ & $\begin{array}{l}0.92^{\mathrm{a}} \\
(0.19)\end{array}$ & $\begin{array}{l}1.13^{b} \\
(0.15)\end{array}$ \\
\hline \multicolumn{10}{|l|}{$\mathrm{MC}(\% \mathrm{db})$} \\
\hline 15 & $\begin{array}{l}48.93^{\mathrm{a}} \\
(3.29)\end{array}$ & $\begin{array}{l}5.19^{c} \\
(0.80)\end{array}$ & $\begin{array}{l}16.61^{\mathrm{a}} \\
(0.36)\end{array}$ & $\begin{array}{l}89.28^{b} \\
(2.30)\end{array}$ & $\begin{array}{l}0.42^{\mathrm{a}} \\
(0.02)\end{array}$ & $\begin{array}{l}3.39^{c} \\
(0.29)\end{array}$ & $\begin{array}{l}15.39^{a} \\
(0.59)\end{array}$ & $\begin{array}{l}0.95^{\mathrm{a}} \\
(0.14)\end{array}$ & $\begin{array}{l}1.15^{b} \\
(0.12)\end{array}$ \\
\hline 25 & $\begin{array}{l}42.31^{b} \\
(1.76)\end{array}$ & $\begin{array}{l}6.61^{\mathrm{a}} \\
(0.58)\end{array}$ & $\begin{array}{l}16.19^{b} \\
(0.71)\end{array}$ & $\begin{array}{l}82.15^{\mathrm{c}} \\
(5.33)\end{array}$ & $\begin{array}{c}0.36^{\mathrm{b}} \\
(0.04)\end{array}$ & $\begin{array}{l}4.25^{\mathrm{b}} \\
(0.38)\end{array}$ & $\begin{array}{l}13.29^{b} \\
(1.04)\end{array}$ & $\begin{array}{l}0.85^{\mathrm{b}} \\
(0.12)\end{array}$ & $\begin{array}{l}1.20^{\mathrm{a}} \\
(0.11)\end{array}$ \\
\hline 35 & $\begin{array}{l}35.17^{\mathrm{c}} \\
(2.87)\end{array}$ & $\begin{array}{l}6.16^{\mathrm{b}} \\
(0.67)\end{array}$ & $\begin{array}{l}12.72^{\mathrm{c}} \\
(0.91)\end{array}$ & $\begin{array}{l}92.27^{\mathrm{a}} \\
(3.08)\end{array}$ & $\begin{array}{c}0.35^{\mathrm{c}} \\
(0.06)\end{array}$ & $\begin{array}{l}4.66^{\mathrm{a}} \\
(0.39)\end{array}$ & $\begin{array}{l}13.21^{\mathrm{b}} \\
(1.64)\end{array}$ & $\begin{array}{l}0.94^{\mathrm{a}} \\
(0.21)\end{array}$ & $\begin{array}{l}1.09^{\mathrm{c}} \\
(0.10)\end{array}$ \\
\hline $\mathrm{T}\left({ }^{\circ} \mathrm{C}\right)$ & & & & & & & & & \\
\hline 110 & $\begin{array}{l}40.58^{\mathrm{c}} \\
(7.24)\end{array}$ & $\begin{array}{c}6.30^{\mathrm{a}} \\
(1.21)\end{array}$ & $\begin{array}{l}15.20^{\mathrm{a}} \\
(2.09)\end{array}$ & $\begin{array}{l}88.99^{a} \\
(5.77)\end{array}$ & $\begin{array}{l}0.41^{\mathrm{a}} \\
(0.02)\end{array}$ & $\begin{array}{c}3.81^{\mathrm{b}} \\
(0.60)\end{array}$ & $\begin{array}{l}13.81^{\mathrm{b}} \\
(1.50)\end{array}$ & $\begin{array}{l}1.07^{\mathrm{a}} \\
(0.12)\end{array}$ & $\begin{array}{l}1.10^{\mathrm{b}} \\
(0.08)\end{array}$ \\
\hline 140 & $\begin{array}{l}43.34^{\mathrm{a}} \\
(6.85)\end{array}$ & $\begin{array}{l}5.72^{\mathrm{c}} \\
(0.81)\end{array}$ & $\begin{array}{l}14.95^{\mathrm{b}} \\
(2.14)\end{array}$ & $\begin{array}{l}86.28^{\mathrm{c}} \\
(6.61)\end{array}$ & $\begin{array}{c}0.37^{\mathrm{b}} \\
(0.04)\end{array}$ & $\begin{array}{l}4.22^{\mathrm{a}} \\
(0.55)\end{array}$ & $\begin{array}{l}13.67^{\mathrm{b}} \\
(1.62)\end{array}$ & $\begin{array}{l}0.90^{\mathrm{b}} \\
(0.13)\end{array}$ & $\begin{array}{l}1.23^{\mathrm{a}} \\
(0.11)\end{array}$ \\
\hline 170 & $\begin{array}{l}42.49^{b} \\
(4.13)\end{array}$ & $\begin{array}{c}5.94^{\mathrm{b}} \\
(0.47)\end{array}$ & $\begin{array}{l}15.37^{\mathrm{a}} \\
(1.37)\end{array}$ & $\begin{array}{l}88.44^{b} \\
(4.25)\end{array}$ & $\begin{array}{c}0.36^{\mathrm{c}} \\
(0.07)\end{array}$ & $\begin{array}{l}4.28^{\mathrm{a}} \\
(0.67)\end{array}$ & $\begin{array}{l}14.41^{\mathrm{a}} \\
(1.44)\end{array}$ & $\begin{array}{c}0.77^{\mathrm{c}} \\
(0.09)\end{array}$ & $\begin{array}{l}1.11^{\mathrm{b}} \\
(0.11)\end{array}$ \\
\hline
\end{tabular}

* Means with different letters in a column within each independent variable are significantly different $(\mathrm{p}<0.05)$ for that independent variable at $\mathrm{p}<0.05$; values in parentheses are standard deviation. $\mathrm{MC}-$ Moisture content of the ingredients; T- Barrel temperature.

\subsection{Pellet Durability Index (PDI)}

Pellet durability indicates the mechanical strength of the extrudates. (Rosentrater et al., 2005). In fact, the extent of heat treatment, along with the level of starch transformation, protein denaturation, and water content, during 
the extrusion processing, influence the pellet durability quality of the extrudates (Rosentrater et al., 2009). The main effects of the independent variables on the extrudate pellet durability are presented in Table 2 . The effect of changing the level of white flakes, moisture content and temperature on pellet durability of extrudates was found to be significant $(\mathrm{p}<0.05$, Table 3$)$ but no definite pattern was observed. As depicted in Table 2, increasing SWF inclusion from $10 \%$ to $20 \%$, moisture content from $15 \%$ to $25 \%$ and temperature from $110{ }^{\circ} \mathrm{C}$ to $140{ }^{\circ} \mathrm{C}$ decreased PDI by $2.6 \%, 8 \%$ and $3.0 \%$, respectively. Whereas, further increasing SWF content from $20 \%$ to $30 \%$, increasing moisture content from $25 \%$ to $35 \%$ and increasing temperature from $140{ }^{\circ} \mathrm{C}$ to $170{ }^{\circ} \mathrm{C}$ resulted in a significant increase $(\alpha=0.05)$ by $5 \%, 12.3 \%$ and $2.5 \%$ in PDI, respectively. Maximum and minimum values of PDI were observed as $89.97 \%$ and $85.73 \%$ at $30 \%$ and $20 \%$ SWF content in ingredient blends respectively, $92.27 \%$ and $82.15 \%$ at $35 \%$ and $25 \%$ moisture content of ingredients respectively and $88.99 \%$ and $86.28 \%$ at $110{ }^{\circ} \mathrm{C}$ and $140{ }^{\circ} \mathrm{C}$ respectively (Table 2). Interaction effect of all independent variables on PDI was significant, $\mathrm{p}<0.0001$ (Table 3).

Table 3. Interaction results for SWF content, moisture content of raw material and barrel temperature on extrudate physical properties ( $\mathrm{p}$ values)

\begin{tabular}{|c|c|c|c|c|c|c|c|c|c|}
\hline Variable & $\begin{array}{l}L^{*} \\
(-)\end{array}$ & $\begin{array}{l}a^{*} \\
(-)\end{array}$ & $\begin{array}{l}b^{*} \\
(-)\end{array}$ & $\begin{array}{l}\text { PDI } \\
(\%)\end{array}$ & $\begin{array}{c}\mathrm{BD} \\
(\mathrm{g} / \mathrm{cc})\end{array}$ & $\begin{array}{c}\text { WAI } \\
(-)\end{array}$ & $\begin{array}{r}\text { WSI } \\
(\%)\end{array}$ & $\begin{array}{c}\text { UD } \\
(\mathrm{g} / \mathrm{cc})\end{array}$ & $\begin{array}{c}\text { ER } \\
(-)\end{array}$ \\
\hline SWF & 0.02 & $<.0001$ & $<.0001$ & $<.0001$ & $<.0001$ & 0.0004 & 0.1046 & 0.0113 & $<.0001$ \\
\hline $\mathrm{MC}$ & $<.0001$ & $<.0001$ & $<.0001$ & $<.0001$ & $<.0001$ & $<.0001$ & $<.0001$ & $<.0001$ & $<.0001$ \\
\hline $\mathrm{SWF} \times \mathrm{MC}$ & 0.0039 & $<.0001$ & 0.0004 & $<.0001$ & $<.0001$ & 0.0431 & 0.008 & $<.0001$ & $<.0001$ \\
\hline $\mathrm{T}$ & $<.0001$ & $<.0001$ & $<.0001$ & $<.0001$ & $<.0001$ & $<.0001$ & 0.0158 & $<.0001$ & $<.0001$ \\
\hline $\mathrm{SWF} \times \mathrm{T}$ & $<.0001$ & $<.0001$ & 0.0153 & $<.0001$ & $<.0001$ & 0.0564 & 0.0016 & 0.0334 & $<.0001$ \\
\hline $\mathrm{MC} \times \mathrm{T}$ & $<.0001$ & $<.0001$ & $<.0001$ & $<.0001$ & $<.0001$ & 0.4202 & 0.8013 & $<.0001$ & $<.0001$ \\
\hline $\mathrm{SWF} \times \mathrm{MC} \times \mathrm{T}$ & $<.0001$ & $<.0001$ & 0.0526 & $<.0001$ & $<.0001$ & 0.714 & 0.2371 & 0.3335 & 0.0044 \\
\hline
\end{tabular}

\subsection{Bulk Density (BD)}

Bulk density influences storage capacity required at the processing plant and during shipping. Increasing SWF content from $10 \%$ to $30 \%$ significantly changed ( $<<0.05$, Table 3 ) BD of the extrudates but no particular trend was observed. Changing the level of moisture content from $15 \%$ to $35 \%$ resulted in a $17 \%$ decrease and increasing the barrel temperature from $110{ }^{\circ} \mathrm{C}$ to $170{ }^{\circ} \mathrm{C}$ resulted in a $12 \%$ decrease in $\mathrm{BD}$. This may be due to the reason that when the melt exits the die nozzle at high temperature it expands more and have more volume than the extrudates exiting at low temperature.

\subsection{Water Absorption Index (WAI) and Water Solubility Index (WSI)}

Water absorption index indicates the amount of water immobilized by the extrudate, while water solubility index indicates the amount of small molecules solubilized in water (Mezreb et al., 2003). WAI is related to the water activity and influences the storage stability. Main effects of independent variables on WAI and WSI are shown in Table 2. When percentage of SWF in ingredient mix was increased from 10 to $30 \%$, a significant increase of $7.0 \%$ in WAI was found. As the moisture content of ingredient was increased from $15 \%$ to $35 \%$ and barrel temperature was increased from $110^{\circ} \mathrm{C}$ to $170{ }^{\circ} \mathrm{C}$, WAI increased by $37.5 \%$ and $12.3 \%$, respectively (Table 2 ). A similar trend was observed by Anderson et al (1969) with extruded sorghum grits. No significant change was observed for WSI as SWF content was increased from $10 \%$ to $30 \%$ in ingredient blends (Table 2). When moisture content was increased from $15 \%$ to $35 \%$ and barrel temperature was increased from $110{ }^{\circ} \mathrm{C}$ to $170{ }^{\circ} \mathrm{C}$ a decrease of $14 \%$ and an increase of $4.3 \%$ in WSI were observed, respectively (Table 2). This may be due to the reason that as the temperature increased, the extent of starch gelatinization increased. According to Harper (1981), WSI of the extrudate is directly related to the extent of starch gelatinization that occurs inside the extruder.

\subsection{Unit Density (UD)}

Unit density influences the floatability of the extrudates. As depicted in Table 2, a significant increase of $3.4 \%$ in UD of the extruded products was observed when level of SWF was raised from $10 \%$ to $30 \%$. The maximum and minimum unit density values were $0.95 \mathrm{~g} / \mathrm{cm}^{3}$ and $0.85 \mathrm{~g} / \mathrm{cm}^{3}$ observed at $15 \%$ and $25 \%$ ingredient moisture 
content, respectively. The apparent viscosity of the ingredient melt inside the barrel and die is inversely proportional to the extruder barrel temperature (Harper et al., 1981; Bhattacharya \& Hanna, 1986). When the ingredient melt having lower viscosity exits through the die, the produced extrudates tend to expand more, and thus have reduced UD. Increasing the barrel temperature from $110{ }^{\circ} \mathrm{C}$ to $170{ }^{\circ} \mathrm{C}$ resulted in a $28 \%$ decrease in UD (Table 2).

\subsection{Expansion Ratio (ER)}

Changes in the level of SWF content, moisture content of ingredient mix and temperature had a significant effect on ER of extrudates (Table 3) but no particular trend was observed. Changing the level of SWF content from $10 \%$ to $20 \%$, a significant decrease of $3.4 \%$ in expansion ratio was observed; further increasing of the SWF inclusion to $30 \%$ had no effect on ER of the extrudates (Table 2).

\section{Conclusions}

The goals of this study were to produce fish feed pellets with HP-DDG and SWF inclusions and to examine the effect of various levels of SWF, moisture content and extruder barrel temperature on physical properties of the extruded feeds. Changing the level of SWF significantly affected extrudate color, pellet durability, bulk density, water absorption index, unit density and expansion ratio $(p<0.05)$. Increasing the level of SWF from $10 \%$ to $30 \%$, significantly increased the value of WAI from 3.98 to 4.26 and UD from $0.89 \mathrm{~g} / \mathrm{cm}^{3}$ to $0.92 \mathrm{~g} / \mathrm{cm}^{3}$ but decreased the value of ER from 1.17 to $1.13(\alpha=0.05)$. Also changing the level of moisture content and temperature had significant effect $(\mathrm{p}<0.05)$ on all physical properties. Increasing moisture content from $15 \%$ to $35 \%$ resulted in a $37.5 \%$ increase in WAI and $17 \%$ and $14 \%$ decrease in bulk density and WSI, respectively. As temperature increased from 110 to $170{ }^{\circ} \mathrm{C}$, WAI and WSI increased by $12.3 \%$ and $4.3 \%$, respectively. But there was a decrease in BD by $12 \%$ and UD by $28 \%$. The interaction effect of SWF content, moisture content and temperature $(\mathrm{SWF} \times \mathrm{MC} \times \mathrm{T})$ were found to be significant for color, $\mathrm{PDI}, \mathrm{BD}$ and $\mathrm{ER}$. All the extrudates showed relatively high pellet durability, which is important to retaining their physical structure during transportation and storage. This indicates that utilization of combined SWF and HP-DDG did not have detrimental effect on pellet durability. Increasing levels of SWF produced less expanded and more compact textured extrudates. Based on the results obtained, further research may be conducted to study the effects of increased level of SWF (more than $30 \%$ ) with different die dimension on the extrudate quality.

\section{Acknowledgements}

The authors are grateful to Indian Council of Agricultural Research (ICAR), New Delhi, India, USDA-North Central Agricultural Research Laboratory, Brookings, South Dakota and Agricultural Experiment Station, South Dakota State University for financial support, facilities, equipment and supplies.

\section{References}

AACC. (2000). Method 44-19, moisture-air oven method, drying at $135^{\circ} \mathrm{C}$. AACC Approved Methods (10th Ed.) American Association of Cereal Chemists: St. Paul, MN.

Anderson, R. A., Conway, H. F., Pfeifer, V. F., \& Griffin, E. L. (1969). Roll and extrusion cooking of grain sorghum grits. Cereal Sci. Today, 14(11), 373-375.

ASAE. (2004). Engineering Standards, Practices and Data. ASABE, St. Joseph, MI.

Bhattacharya, M., \& Hanna, M. A. (1986). Viscosity modeling of dough in extrusion. International Journal of Food Science \& Technology, 21(5), 167-174. http://dx.doi.org/10.1111/j.1365-2621.1986.tb00438.x

Bjorck, I., \& Asp, N. G. (1983). The effects of extrusion cooking on nutritional value - A literature review. Journal of Food Engineering, 2(4), 281-308. http://dx.doi.org/10.1016/0260-8774(83)90016-X

Dersjant-Li, Y. (2002). The use of soy protein in aquafeeds. In The use of soy protein in aquafeeds. In Cruz-suárez, 1. E., ricque-marie, d., tapia-salazar, m., gaxiola-cortés, m. G., simoes, n. (Eds.). Avances en nutriciónacuícolavi. Memorias del vi symposium 76 internacional de nutriciónacuícola. 3 al 6 deseptiembredel 2002. Cancún, quintanaroo, méxico

Fallahi, P., Muthukumarappan, K., Rosentrater, K. A., \& Brown, M. L. (2012). Twin-screw Extrusion Processing of Vegetable-based Protein Feeds for Yellow Perch (Perca flavescens) Containing Distillers Dried Grains, Soy Protein Concentrate, and Fermented High Protein Soybean Meal. Journal of Food Research, 1(3), 230-246. http://dx.doi.org/10.5539/jfr.v1n3p230

Fallahi, P., Rosentrater, K. A., Muthukumarappan, K., \& Brown M. L. (2013). Twin-screw Extrusion Processing of Rainbow trout (Oncorhynchus mykiss) Feeds using Graded Levels of High Protein Corn-based Distillers 
Dried Grains (HP-DDG) and Conventional Distillers Dried Grains with Solubles (DDGS). Journal of Food Research, 2(1), 118-139. http://dx.doi.org/10.5539/jfr.v2n1p118

FAO. (2004). State of World Fisheries and Aquaculture 2004. FAO, Rome, Italy.

Francesco, M. De., Parisi, G., Perez-Sanchez, J., Gomez-Requeni, P., Medale, F. Kaushik, S. J., Mecatti, M., \& Poli, B. M. (2007). Effect of high-level fish meal replacement by plantproteins in gilthead sea bream (Sparus aurata) on growth and body/fillet quality traits. Aquaculture Nutrition, 13(5), 361-372. http://dx.doi.org/10.1111/j.1365-2095.2007.00485.x

Hardy, R. W., \& Masumoto, T. (1990). Specifications for marine by-products for aquaculture. In S. Keller (Ed.), Proc. Int. Conf. on Fish By-products. Anchorage, AK. Alaska Sea Grant College Program. pp. 109-120.

Harper, J. M. (1981). Extrusion of foods. Vol. 1 \& 2. CRC Press Inc: Florida.

Hossain, M. A., \& Jauncey, K. (1989). Nutritional evaluation of some Bangladeshi oil seed meals as partial substitutes for fish meal in the diets of common carp, Cyprinus carpio L. Aqua Fish Manag, 20(3), 255-268. http://dx.doi.org/10.1111/j.1365-2109.1989.tb00351.x

Karalazos, V., Treasurer, J., Cuts, C. C., Alderson, R., Galloway, T. F., Albrektsen, S., Arnason, J., Macdonald, N., Pike, I., \& Bell, G. (2007). Effects of fish meal replacement with full-fat soy meal on growth and tissue fatty acid composition in Atlantic cod (Gadus morhua). Journal of Agricultural and Food Chemistry, 55(14), 5788-5795. http://dx.doi.org/10.1021/jf0629383

Lovell, T. (1989). Nutrition and Feeding of Fish. Van Nostrand Rheinhold: New York.

Lunger, A. N., McLean, E., \& Craig, S. R. (2007). The effects of organic protein supplementation upon growth, feed conversion and texture quality parameters in juvenile cobia (Rachycentron canadum). Aquaculture, 264(1-4), 342-352. http://dx.doi.org/10.1016/j.aquaculture.2006.12.012

Marine Aquaculture Task Force. (2007). Sustainable Marine Aquaculture: Fulfilling the Promise; Managing the Risks," Takoma Park, MD, January 2007. p. 93. Retrieved August 01, 2013 from, http://seafoodforthefuture.org/aquaculture-efficiency-and-feeds/

Mercier, C., Linko, P., \& Harper, J. M. (1989). Extrusion Cooking. American Association of Cereal Chemists. Inc., St. Paul, Minnesota, USA.

Mezreb, K., Goullieux, A., Ralainirina, R., \& Queneudec, M. (2003). Application of image analysis to measure screw speed influence on physical properties of corn and wheat extrudates. Journal of Food Engineering, 57(2), 145-152.

Morris, P. C., Gallimore, P., Handley, J., Hide, G., Haughton, P., \& Black, A. (2005). Full-fat soya for rainbow trout (Oncorhynchus mykiss) in freshwater: Effect on performance, composition and flesh fatty acid profile in absence of hind-gut enteritis. Aquaculture, 248(1-4), 147-161. http://dx.doi.org/10.1016/j.aquaculture.2005.04.021

Renukaradhya, K. M., \& Varghese, T. J. (1986). Protein requirement of the Carps, Catla catla (Hamilton) and Labeo rohita (Hamilton). Proceedings: Animal Sciences, 95(1), 103-107. http://dx.doi.org/10.1007/BF03179363

Robinson, E. H., \& Li. M. H. (2008). Replacement of Soybean Meal in Channel Catfish, Ictaluruspunctatus, Diets with Cottonseed Meal and Distiller's Dried Grains with Solubles. J. World Aquacult. Soc, 39, 521-527. http://dx.doi.org/10.1111/j.1749-7345.2008.00190.x

Robinson, P. H., Karges, K., \& Gibson, M. L. (2008). Nutritional evaluation of four co product feedstuffs from the motor fuel ethanol distillation industry in the Midwestern USA. J. Anim. Feed Sci. Technol., 146, 345-352. http://dx.doi.org/10.1016/j.anifeedsci.2008.01.004

Romarheim, O. H., Aslaksen, M. A., Storebakken, T., Krogdahl, A., \& Skrede, A. (2005). Effect of extrusion on trypsin inhibitor activity and nutrient digestibility of diets based on fish meal, soybean meal and white flakes. Archives of Animal Nutrition, 59(6), 365-375 http://dx.doi.org/10.1080/17450390500352897

Rosentrater, K. A., Richard, T. L., Bern, C. J., \& Flores, R. A. (2005). Small-scale extrusion of corn masa by-products. Cereal Chemistry, 82(4), 436-446. http://dx.doi.org/10.1094/CC-82-0436

Rosentrater, K. A., Muthukumarappan, K. (2006). Corn ethanol coproducts: Generation properties, and future prospects. Int. Sugar J., 108, 648-657.

Rosentrater, K. A., Muthukumarappan, K., \& Kannadhason, S. (2009). Effects of ingredients and extrusion 
parameters on aquafeeds containing DDGS and potato starch. J. Aquacult. Feed Sci. Nutr., 1(1), 22-38.

SAS. (2008). Windows NT Version 9.2. Cary, NC: SAS Institute, Inc.

Spiehs, M. J., Whitney, M. H., \& Shurson, G. C. (2002). Nutrient database for distiller's dried grains with solubles produced from new ethanol plants in Minnesota and South Dakota. J. Anim. Sci, 80, 2639-2645.

USDA. (1999). Practical procedures for grain handlers: Inspecting grain. Grain Inspection, Packers, and Stockyards Administration, United States Department of Agriculture. Washington, D.C. Retrieved June 10, 2012 from http://archive.gipsa.usda.gov/pubs/primer.pdf

\section{Copyrights}

Copyright for this article is retained by the author(s), with first publication rights granted to the journal.

This is an open-access article distributed under the terms and conditions of the Creative Commons Attribution license (http://creativecommons.org/licenses/by/3.0/). 